\title{
PERCEIVED VALUE AND DESTINATION IMAGE ENHANCED ENVI- RONMENTAL AWARENESS IN GREEN HOTEL INDUSTRY: THE ME- DIATING EFFECT OF CORE COMPETENCIES
}

\author{
H. Rasidah ${ }^{*}$, M. H. Azman Ong², N. Baba1 ${ }^{1}$, M. A. Burhanuddin 3 , J. Jamil1 ${ }^{1}$, H. Hassan ${ }^{1}$, A. Mohd \\ Shahril ${ }^{1}$ \\ ${ }^{1}$ Faculty of Hotel and Tourism Management, Universiti Teknologi MARA, 42300 Puncak Alam, Se- \\ langor, Malaysia \\ ${ }^{2}$ Faculty of Computer and Mathematical Sciences, Universiti Teknologi MARA, 85000 Segamat, Jo- \\ hor, Malaysia \\ ${ }^{3}$ Faculty of Business Management, Universiti Teknologi MARA, 85000 Segamat, Johor, Malaysia \\ *rasidah9898@salam.uitm.edu.my
}

\begin{abstract}
This study proposed an integrated theoretical model of hotel industry's green core competencies. An empirical assessment of the theoretical framework for this study included a survey of 337 guests in Malaysian certified green hotels. The resulting data were analyzed using the Partial Least Square Consistency (PLSc) method using the SmartPLS 3.0 software. The findings indicated that perceived values and core competencies have a positives significant effect toward destination image. The competencies also give a positive significant effect toward destination image. All targeted variables were all contributed to improving understanding the underlying relationships. In addition, the study also confirms that core competencies had partial mediation effects between perceived value and destination image. Green hotel investment for the development of core competencies in green segments was helpful to hotel industry for the enhancement of perceived value and destination image.
\end{abstract}

Keywords: Perceived Value, Destination Image, Core Competencies, Green Hotel, Partial Least Square Consistency (PLSc)

\section{INTRODUCTION}

Recently, hotel industry has become increasingly interested in the green practices which enable the industry to become more competitive. The awareness of environmental issues has been raised due to an escalating number of environmental laws and increasing pressure to become green. The existence of written environment policy is associated with the higher level of adoption of green practices in the industry. Environmental programs are steadily increasing within the industry throughout the globe. Businesses including hotels have become much more aware of the environmental performance and both short and long-term profitability (Yusof et al., 2017). The ecological concerns have impact consumers purchasing behavior and demand towards environmentally product and services. The hotel industry in particular has been criticized for its excessive use of non-renewable and non-recyclable resources and its above average use of energy (International Hotels and Restaurants Association, 2015). It is not deniable this industry has also the potential threatening condition of natural environment (Hamid et al., 2016; Rasidah et al., 2014). A good understanding of the core competencies green awareness model in hotel industry is crucial in ensuring high level of green awareness in promoting tourism sustainable development. Ignoring this issue could lead to imbalance of ecosystem, environment sustainability and other unfavorable quality of life effects. This study aims to examine the influence of perceived value towards the destination image and to examine the mediating role of core competencies within the linkages.

LITERATURE REVIEW

Perceived Value

Submit Date: 05.07. 2018, Acceptance Date: 27.08.2018, DOI NO: 10.7456/1080SSE/101

Research Article - This article was checked by Turnitin

Copyright (C) The Turkish Online Journal of Design, Art and Communication 
Sweeney and Soutar (2001) developed a perceived value scale comprising of five dimensions that were termed emotional, social, quality/performance, price/value for money and epistemic value. Previous research studies suggest that perceived value may be a better predictor of repurchase intentions than either satisfaction or quality (Rasidah et al., 2017). Therefore, an in depth study on the relationships between perceived value and behavioral intentions suggests that perceived value can be analyzed with either a self-reported unidimensional measure or a multidimensional scale. In the study, five perceived value variables tested were consists of functional value (performance/quality), functional of value (price/value for money), social value, emotional value and epistemic value.

\section{Core Competencies}

The term competency is the ability to put the skills and knowledge into skills, the core feature, or traits of an individual and how they integrate them in an application (Boyatzis, 1982). Theory of competency is introduced by Prahalad and Hamel (2006) which called as core competency theory, which focuses on a collective learning of an organization on how to coordinate and integrate resources to achieve core competencies. The responsibility of this activity lies in the managerial ability to responds using company resources to achieve core competencies (Mitchelmore \& Rowley, 2010). The researchers also mentioned that this theory is consistent with The Resource Based View of the firm alongside with the government initiatives to support environmental issues, the understanding of core competencies factors affecting environmental awareness and environmental initiatives in hotel industry is important. In other words, it will help the hoteliers to discover their strengths and uncover their potential towards environmental sustainability. In this study, the core competencies variables tested were customer competencies and technology competencies.

\section{Destination Image}

Kim and Richardson (2003) defined destination image as an expression of knowledge, impressions, prejudices, imaginations and emotional thoughts an individual has of a specific place. Agreeing by Beerli and Martin (2004) about characteristics of destination image, they proposed fully detailed characteristics into 9 parts which are natural resources; regular infrastructures; tourism infrastructures; tourism leisure and entertainment; culture, history and arts; political and economic elements; natural environment; social environment and local atmosphere. Destination image was commonly used by scholars and researchers and verified the reasonability of this category by practice. In this study, four destination image variables were tested namely attractive scenery, high-quality green attractions, many to see and do for green program and re-visit intention towards green destination.

\section{Theoretical Framework}

Based on the theoretical backgrounds explained earlier, this study derives a theoretical model that shows the theoretical relationship between Perceived Value, Core Competencies and Destination Image (see Figure 1). Therefore, the following hypothesis was anticipated:

H1: There is a significant relationship between perceived value and destination image

$\mathrm{H} 2$ : There is a significant relationship perceived value and core competencies.

H3: There is a significant relationship between core competencies and destination image

H4: Core Competencies mediated the relationship between perceived value and destination image.

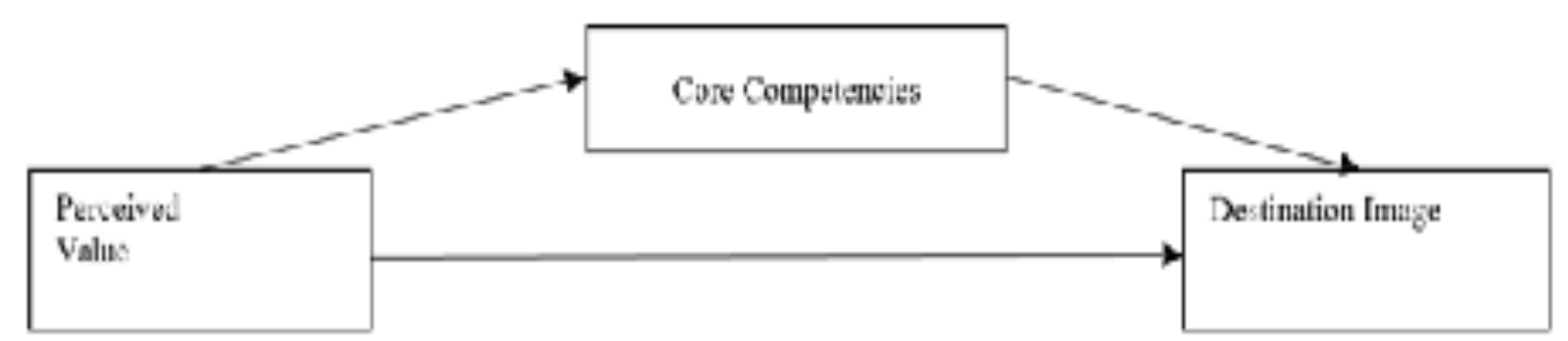

Figure 1. Framework model

\section{METHODOLOGY \\ Sample}


The data used in this study consists of questionnaire responses from participants who visited the certified green hotels in Klang Valley, Malaysia. 450 questionnaires were distributed and 337 responses were received, yielding a response rate of $75 \%$. In order to collect the data, a cover letter has been attached to each set of the questionnaire informing the purpose of the study to the participants. The questionnaire was personally distributed to the person in charge of the Rooms Division Department. Three weeks were given to the Rooms Division Department to distribute the questionnaires in the hotel rooms. After three weeks, a telephone call has been used to remind the person in charge that the questionnaire will be collected.

\section{Analytical Method}

The resulting data were analyzed using the consistent partial least square (PLSc) method. This method allows the researcher to confirm the purposed theory since this PLSc give the researcher to estimate the goodness of fit of the data by mimic the covariance-based SEM approach (Dijkstra, 2014; Dijkstra \& Henseler, 2015). Besides that, this method also permits the researcher to testing both convergent and discriminant validities of the model measurement (Hair et al., 2017). Since the proposed theoretical framework consists of higher order construct (HOC), two-stage approach modeling technique was used due to more practical when handling the HOC models (Henseler \& Chin, 2010). It is indicated that latent variable scores (LVS) that are initially estimated at the first stage was used as the indicators for the HOC at the second stage (Hair et al., 2017).

\section{RESULTS AND DISCUSSION}

\section{First Order Measurement Model}

The quality of the first order measurement was tested first using the PLSc method. Table 1 indicated that all indicators meet the minimum requirement of the convergent validity such as indicator load ${ }^{-}$ ing $>0.70$, AVE $>0.50$ and also both reliability (composite reliability and Cronbach's Alpha) were above 0.70 (Hair et al., 2012; 2017). Besides that, Table 2 indicated that Heterotrait-Monotriat (HTMT) ratio values were less than 0.90 . Hence, it confirms that each latent variable was totally discriminant to each order (Hair et al., 2017; Henseler et al., 2015).

Table 1. Convergent validity for first-order measurement model

\begin{tabular}{|c|c|c|c|c|c|}
\hline $\mathbf{L V}$ & Indicator & Loading & AVE & Composite Reliability & Cronbach's Alpha \\
\hline \multirow{3}{*}{$\begin{array}{l}\text { Quality } \\
\text { Value }\end{array}$} & QualV1 & $.915 * *$ & \multirow[t]{3}{*}{.812} & \multirow[t]{3}{*}{.928} & \multirow[t]{3}{*}{.921} \\
\hline & QualV2 & $.911^{* *}$ & & & \\
\hline & QualV3 & $.876^{* *}$ & & & \\
\hline \multirow{3}{*}{$\begin{array}{l}\text { Price } \\
\text { Value }\end{array}$} & PriceV1 & $.901 * *$ & \multirow{3}{*}{.841} & \multirow{3}{*}{.941} & \multirow{3}{*}{.936} \\
\hline & PriceV2 & $.895 * *$ & & & \\
\hline & PriceV3 & $.954 * *$ & & & \\
\hline \multirow{3}{*}{$\begin{array}{l}\text { Social } \\
\text { Value }\end{array}$} & SocialV1 & $.872 * *$ & \multirow{3}{*}{.733} & \multirow{3}{*}{.891} & \multirow{3}{*}{.901} \\
\hline & SocialV2 & $.881 * *$ & & & \\
\hline & SocialV3 & $.813 * *$ & & & \\
\hline \multirow{3}{*}{$\begin{array}{l}\text { Emotional } \\
\text { Value }\end{array}$} & EmoV1 & $.736^{* *}$ & \multirow{3}{*}{.558} & \multirow{3}{*}{.791} & \multirow{3}{*}{.813} \\
\hline & EmoV2 & $.789 * *$ & & & \\
\hline & EmoV3 & $.714 * *$ & & & \\
\hline \multirow[b]{2}{*}{ Fnistemic } & EpisV1 & $.895 * *$ & \multirow[b]{2}{*}{709} & \multirow[b]{2}{*}{907} & \multirow[b]{2}{*}{893} \\
\hline & EpisV2 & $.816^{* *}$ & & & \\
\hline
\end{tabular}


The Turkish Online Journal of Design, Art and Communication - TOJDAC

ISSN: 2146-5193, September 2018 Special Edition, p.693-700

\begin{tabular}{|c|c|c|c|c|c|}
\hline \multirow[t]{2}{*}{ Value } & EpisV3 & $.804 * *$ & & \multirow{2}{*}{$\cdots$} & \multirow[t]{2}{*}{$\cdots$} \\
\hline & EpisV4 & $.851 * *$ & & & \\
\hline \multirow{3}{*}{$\begin{array}{c}\text { Customer } \\
\text { Competencies }\end{array}$} & Cus 1 & $.863 * *$ & \multirow{3}{*}{.712} & \multirow{3}{*}{.881} & \multirow{3}{*}{.892} \\
\hline & Cus2 & $.842 * *$ & & & \\
\hline & Cus3 & $.826 * *$ & & & \\
\hline \multirow{3}{*}{$\begin{array}{c}\text { Technology } \\
\text { Competencies }\end{array}$} & Tech1 & $.796 * *$ & \multirow{3}{*}{.583} & \multirow{3}{*}{.807} & \multirow{3}{*}{.796} \\
\hline & Tech2 & $.716^{* *}$ & & & \\
\hline & Tech3 & $.776^{* *}$ & & & \\
\hline \multirow{3}{*}{$\begin{array}{l}\text { Attractive } \\
\text { Scenery }\end{array}$} & Sce1 & $.812 * *$ & \multirow{3}{*}{.644} & \multirow{3}{*}{.845} & \multirow{3}{*}{.864} \\
\hline & Sce2 & $.803 * *$ & & & \\
\hline & Sce3 & $.793 * *$ & & & \\
\hline \multirow{3}{*}{$\begin{array}{c}\text { Green } \\
\text { Attraction }\end{array}$} & Green1 & $.896^{* *}$ & \multirow{3}{*}{.833} & \multirow{3}{*}{.937} & \multirow{3}{*}{.893} \\
\hline & Green2 & $.913 * *$ & & & \\
\hline & Green3 & $.929 * *$ & & & \\
\hline \multirow{3}{*}{$\begin{array}{c}\text { Green } \\
\text { Promotion }\end{array}$} & Promo1 & $.936 * *$ & \multirow{3}{*}{.870} & \multirow{3}{*}{.953} & \multirow{3}{*}{.946} \\
\hline & Promo2 & $.915^{* *}$ & & & \\
\hline & Promo3 & $.947 * *$ & & & \\
\hline \multirow{3}{*}{$\begin{array}{l}\text { Revisit } \\
\text { Intention }\end{array}$} & Rev1 & $.879 * *$ & \multirow{3}{*}{.773} & \multirow{3}{*}{.911} & \multirow{3}{*}{.923} \\
\hline & Rev2 & $.883^{* *}$ & & & \\
\hline & Rev3 & $.876^{* *}$ & & & \\
\hline
\end{tabular}

Note: $\mathrm{LV}=$ Latent Variable; AVE $=$ Average Variance Explained; $* * \mathrm{p}<0.01$.

In addition, the Standardized Root-Mean Squared Residual (SRMR) and the Normed Fit Index (NFI) for this measurement model were 0.059 (SRMR < 0.080) and 0.908 (NFI > 0.90). Hence, it is indicated that this first order model fits the empirical data (Hair et al., 2017). Therefore, the LVS from this model can be used since meet the requirement of convergent and discriminant validities as well as having a credible goodness of fit index. 
Table 2. HTMT discriminant analysis for first-order measurement model

\begin{tabular}{|c|c|c|c|c|c|c|c|c|c|c|}
\hline & $\mathbf{( 1 )}$ & $\mathbf{( 2 )}$ & $\mathbf{( 3 )}$ & $\mathbf{( 4 )}$ & $\mathbf{( 5 )}$ & $\mathbf{( 6 )}$ & $\mathbf{( 7 )}$ & $\mathbf{( 8 )}$ & $\mathbf{( 9 )}$ & $\mathbf{( 1 0 )}$ \\
\hline$(1)$ & & & & & & & & & & \\
\hline$(2)$ & 0.795 & & & & & & & & & \\
\hline$(3)$ & 0.401 & 0.601 & & & & & & & & \\
\hline$(4)$ & 0.710 & 0.520 & 0.532 & & & & & & & \\
\hline$(5)$ & 0.235 & 0.445 & 0.636 & 0.698 & & & & & & \\
\hline$(6)$ & 0.189 & 0.429 & 0.423 & 0.237 & 0.715 & & & & & \\
\hline$(7)$ & 0.436 & 0.432 & 0.873 & 0.587 & 0.852 & 0.441 & & & & \\
\hline$(8)$ & 0.503 & 0.241 & 0.603 & 0.699 & 0.569 & 0.523 & 0.508 & & & \\
\hline$(9)$ & 0.357 & 0.357 & 0.420 & 0.381 & 0.524 & 0.178 & 0.407 & 0.403 & & \\
\hline$(10)$ & 0.433 & 0.237 & 0.571 & 0.415 & 0.147 & 0.403 & 0.496 & 0.369 & 0.369 & \\
\hline$(11)$ & 0.210 & 0.128 & 0.523 & 1.190 & 0.516 & 0.595 & 0.557 & 0.690 & 0.498 & 0.516 \\
\hline
\end{tabular}

Note: (1) = Quality Value; (2) = Price Value; (3) = Social Value; (4) = Emotional Value; (5) = Epistemic Value; (6) = Customer Competencies; (7) = Technology Competencies; (8) = Attractive Scenery; (9) = Green Attraction; (10) = Green Promotion; (11) = Revisit Intention.

\section{Second Order Measurement Model}

All indicators for measuring the target latent variables in the second order measurement model (Table 3 ) also meet the minimum requirement of convergent validity (indicator loading $>0.70$, AVE $>$ 0.50, Composite Reliability and Cronbach's Alpha were > 0.70) (Hair et al., 2012; 2017). However, there are some indicators having loading value $>0.50$. But, this indicator was maintained in the analysis if the AVE for the specific latent variable was above 0.50 for maintain the content validity (Hair et al., 2017). In addition, the HTMT ratio values for this model (Table 4) were also less than 0.90 . Therefore, latent variables used in this model were totally discriminant to each order (Hair et al., 2017: Henseler et al., 2015). Furthermore, the Standardized Root-Mean Squared Residual (SRMR) and the Normed Fit Index (NFI) for this measurement model were 0.046 (SRMR < 0.080) and 0.913 (NFI > 0.90). Hence, it is indicated that this second order model fits the empirical data (Hair et al., 2017). Therefore, the structural model and mediating test can be evaluated.

Table 3. Convergent validity for second-order measurement model

\begin{tabular}{|c|c|c|c|c|c|}
\hline LV & Indicator & $\begin{array}{c}\text { Loadin } \\
\text { g }\end{array}$ & AVE & $\begin{array}{c}\text { Composite } \\
\text { Reliability }\end{array}$ & $\begin{array}{c}\text { Cronbach's } \\
\text { Alpha }\end{array}$ \\
\hline \multirow{3}{*}{$\begin{array}{c}\text { Perceived } \\
\text { Value }\end{array}$} & Quality Value & $.644 *$ & & & \\
\cline { 2 - 3 } & Price Value & $.591 * *$ & \multirow{2}{*}{.521} & .843 & .845 \\
\cline { 2 - 3 } & Social Value & $.793 * *$ & & & \\
\cline { 2 - 3 } & Emotional Value & $.787 * *$ & & & \\
\cline { 2 - 3 } & Epistemic Value & $.770^{* *}$ & & & \\
\hline
\end{tabular}




\begin{tabular}{|c|c|c|c|c|c|}
\hline \multirow{2}{*}{$\begin{array}{c}\text { Core } \\
\text { Competenci } \\
\text { es }\end{array}$} & $\begin{array}{c}\text { Customer } \\
\text { Competencies }\end{array}$ & $.821 * *$ & \multirow[t]{2}{*}{.652} & \multirow[t]{2}{*}{.789} & \multirow[t]{2}{*}{.789} \\
\hline & $\begin{array}{c}\text { Technology } \\
\text { Competencies }\end{array}$ & $.793 * *$ & & & \\
\hline \multirow{4}{*}{$\begin{array}{l}\text { Destination } \\
\text { Image }\end{array}$} & Attractive Scenery & $.782 * *$ & \multirow{4}{*}{.516} & \multirow{4}{*}{.810} & \multirow{4}{*}{.810} \\
\hline & Green Attraction & $.703 * *$ & & & \\
\hline & Green Promotion & $.680^{* *}$ & & & \\
\hline & Revisit Intention & $.705 * *$ & & & \\
\hline
\end{tabular}

Note: $\mathrm{LV}=$ Latent Variable; $\mathrm{AVE}=$ Average Variance Explained; $* * \mathrm{p}<0.01$.

The structural analysis indicated that Perceived Value can give explanation about $23.3 \%$ toward Core Competencies. Whereas, in term of simultaneous concept, Perceived Values and Core Competencies were able to explain about $65.0 \%$ of variance toward Destination Image. In addition, the effect size $\left(\mathrm{f}^{2}\right)$ and predictive relevance $\left(\mathrm{q}^{2}\right)$ for each path can be considered as weak to large effect (Hair et al., 2012).

Table 4. HTMT discriminant analysis for second-order measurement model

\begin{tabular}{|c|c|c|c|}
\hline & (1) & (2) & (3) \\
\hline$(1)$ & & & \\
\hline$(2)$ & 0.717 & & \\
\hline$(3)$ & 0.481 & 0.661 & \\
\hline
\end{tabular}

Note: $(1)=$ Perceived Values; $(2)=$ Core Competencies; (3) = Destination Image.

\section{Structural Model and Mediating Testing}

Table 5 indicated that Perceived Values have a significant positive effect toward Core Competencies $(\beta=0.483, t=9.762, p<0.01 ; 95 \%$ BCa CI: $(0.376,0.573))$ and also Destination Image $(\beta=0.418, t=$ $7.343, \mathrm{p}<0.01 ; 95 \%$ BCa CI: $(0.299,0.522))$. In addition, the analysis also confirms that Core Competencies also give a positive effect toward Destination Image $(\beta=0.517, \mathrm{t}=8.769, \mathrm{p}<0.01 ; 95 \% \mathrm{BCa}$ CI: $(0.404,0.636))$. Therefore, it confirms that if the average level of Perceived Values was high, then the level of Core Competencies and Destination Image was also high. Besides that, in the same way, then the average level of Core Competencies was high, then the average of Destination Image tends to be high.

Table 5. Structural model assessment for second-order measurement model

\begin{tabular}{|c|c|c|c|c|c|}
\hline & $\boldsymbol{\beta}$ & t-Statistic & $\mathbf{9 5 \%}$ BCa Confidence Intervala & $\mathbf{f}^{2}$ & \\
\hline $\mathrm{PV} \rightarrow \mathrm{CC}$ & 0.483 & $9.762^{* *}$ & $(0.376,0.573)$ & & $\mathbf{q}^{\mathbf{2}}$ \\
\hline $\mathrm{CC} \rightarrow \mathrm{DI}$ & 0.517 & $8.769^{* *}$ & $(0.404,0.636)$ & 0.483 & .198 \\
\hline $\mathrm{PV} \rightarrow \mathrm{DI}$ & 0.418 & $7.343^{* *}$ & $(0.299,0.522)$ & 0.667 & .256 \\
\hline
\end{tabular}

Note: $\mathrm{PV}=$ Perceived Values; $\mathrm{CC}=$ Core Competencies; $\mathrm{DI}=$ Destination Image; $\beta=$ Standardized

Beta Coefficient; $\mathrm{BCa}=$ Bias Corrected and Accelerated; $\mathrm{f}^{2}=$ Effect Size; $\mathrm{q}^{2}=$ Predictive Relevance; 
aThe bootstrap samples was 5000 samples; ${ }^{* *} \mathrm{p}<0.01$.

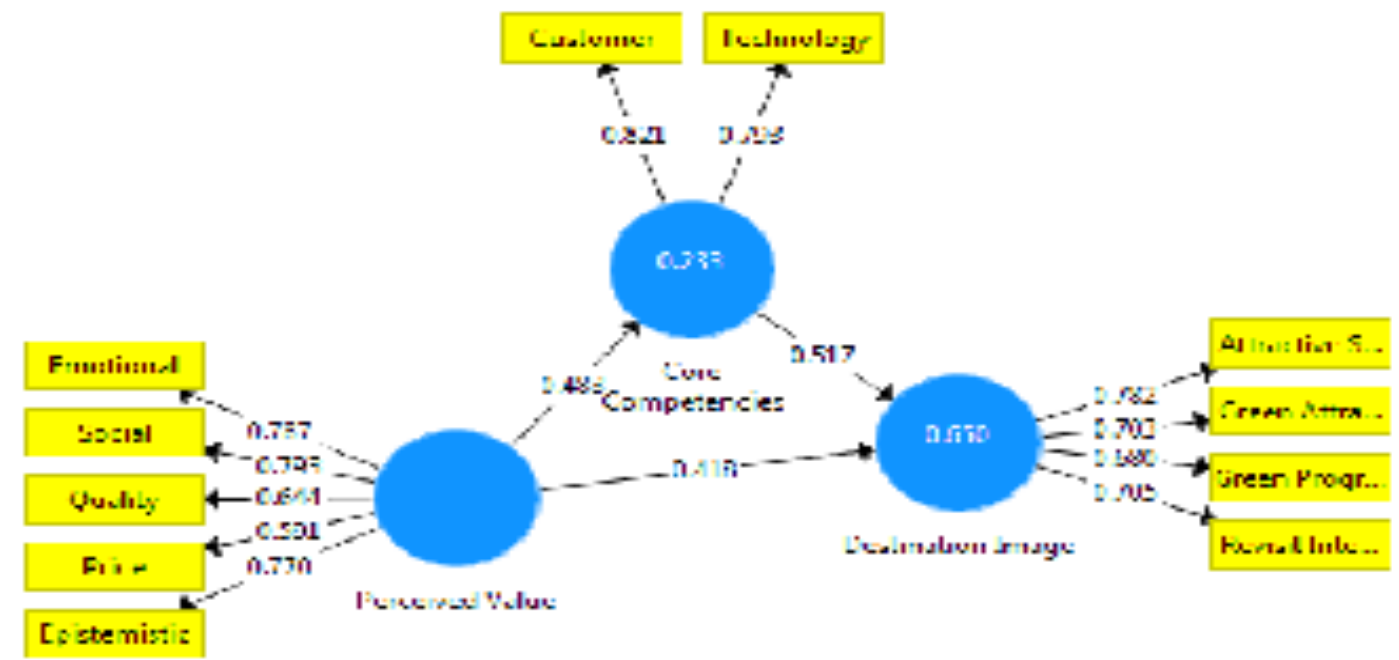

Figure 2. Loading assessment

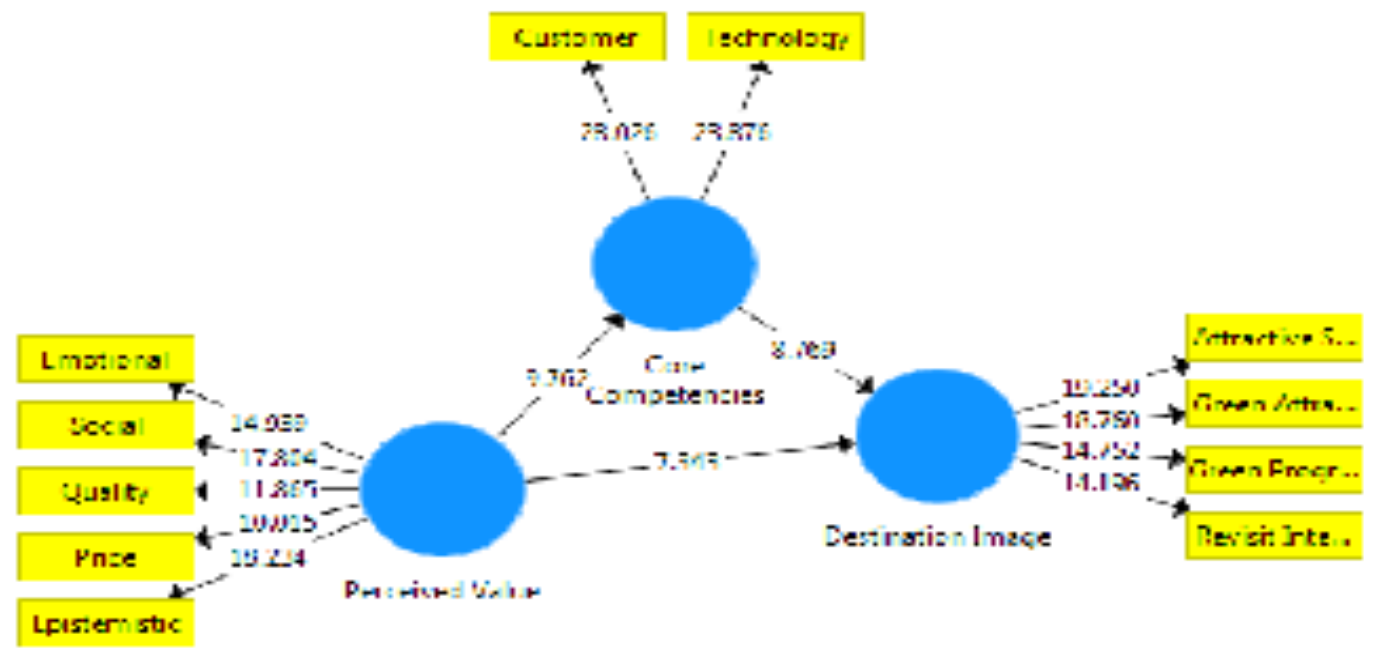

Figure 3. Bootstrapping assessment

The indirect effect assessment also confirms that Core Competencies mediated the relationship between Perceived Values and Destination Image since the indirect path of PV $\rightarrow \mathrm{CC} \rightarrow$ DI was significant and supported by the assessment of indirect bootstrapping analysis (Indirect Effect: $0.250, \mathrm{t}=6.709, \mathrm{p}<0.01 ; 95 \%$ BCa CI: $(0.182,0.330)$ ) (Hair et al., 2017). The analysis also confirms that there is partially mediating effect of Core Competencies between the relationship of Perceived Values and Destination Image, since the direct effect of Perceived Values toward Destination Image was significant (Zhao et al., 2010).

\section{CONCLUSION}

The primary objectives of this study were to investigate and develop a theoretical relationship among perceived value, core competencies and destination image which in turn influence destination loyalty. The SmartPLS analysis supported the existence of statistically significant relationships between perceived value and destination image (H1), perceived value and core competencies (H2), core competencies and destination image (H3). On the other hands, the findings conclude that core competencies mediates the relationship between perceived value and destination image (H4). This indicates that perceived value and core competencies are important variables influencing destination image. Limitations and Future Directions: There are two major limitations worth noting in this study, which are relating to the sample size and the industry involved. Since this study is confined to green hotel guests in Klang Valley area, generalizibility of the findings may be rather limited. There- 
fore, future research may need to focus on green hotel guests in other states in order to gain more comprehensive perspective and stronger representativeness of the study in the local context. Future research also may extends in other service industries such as retail or public transportation industry as no such research has been conducted in those industries in Malaysia.

\section{ACKNOWLEDGEMENTS}

The work described in this paper was supported by LESTARI Research Grant Scheme under Institute of Research Management and Innovation (IRMI) Universiti Teknologi MARA (600-IRMI/ Dana KCM 5/3/LESTARI (136/2017). The suggestions made by the anonymous reviewers and researchers are gratefully acknowledged. Further appreciation is dedicated to the supervisory committees for supporting in finishing up this research study.

\section{REFERENCES}

Beerli, A., \& Martin, J. D. (2004). Factors influencing destination image. Annals of Tourism Research, 31(3), 657-681.

Boyatzis, R. E. (1982). The competent manager: A model for effective performance. John Wiley and Sons.

Dijkstra, T. K. (2014). PLS' janus face-Response to professor Rigdon's 'rethinking partial least squares modeling: In praise of simple methods'. Long Range Planning, 47(3), 146-153.

Dijkstra, T. K., \& Henseler, J. (2015). Consistent partial least squares path modeling. MIS Quarterly, 39(2), 297-316.

Hair, J. F., Hult, G. T. M., Ringle, C. M., \& Sarstedt, M. (2017). A primer on partial least squares structural equation modeling (PLS-SEM). Sage Publications.

Hair, J. F., Sarstedt, M., Ringle, C. M., \& Mena, J. A. (2012). An assessment of the use of partial least squares structural equation modeling in marketing research. Journal of the Academy Marketing Science, 40(3), 414-433.

Hamid, R., Jamal, S. A., Sumarjan, N., \& Ong, M. H. (2016). Perceived value antecedents and guest satisfaction in Malaysian green hotels. In 3rd International Hospitality and Tourism Conference and 2nd International Seminar on Tourism.

Henseler, J., \& Chin, W.W. (2010). A comparison of approaches for the analysis of interaction effects between latent variables using partial least squares path modeling. Structural Equation Modeling: A Multidisciplinary Journal, 17(1), 82-109.

Henseler, J., Ringle, C. M., \& Sarstedt, M. (2015). A new criterion for assessing discriminant validity in variance-based structural equation modeling. Journal of the Academy Marketing Science, 43(1), $115-135$.

International Hotels and Restaurants Association. (2015). Message from the IHRA president. http://ihra.com/message-from-the-ihra-president.

Kim, H., \& Richardson, S. L. (2003). Motion picture impacts on destination images. Annals of Tourism Research, 30(1), 216-237.

Mitchelmore, S., \& Rowley, J. (2010). Entrepreneurial competencies: A literature review and development agenda. International Journal of Entrepreneurial Behavior and Research, 16(2), 92-111.

Prahalad, C. K., \& Hamel, G. (2006). The core competence of the corporation. In Strategische Unternehmungsplanung — Strategische Unternehmungsführung. Springer, pp. 275-292.

Rasidah, H., Jamal, S. A., \& Sumarjan, N. (2014). A conceptual study of perceived value and behavioral intentions in green hotels. Australian Journal of Basic and Applied Sciences, 8(5), 254-259.

Rasidah, H., Jamal, S. A., Sumarjan, N., \& Ong, M. H. A. (2017). Perceived value and behavioral intentions relationship: A test of mediation model in Malaysian green hotels. Advanced Science Letters, 23(8), 7359-7362.

Sweeney, J. C., \& Soutar, G. N. (2001). Consumer perceived value: The development of a multiple item scale. Journal of Retailing, 77(2), 203-220.

Yusof, Y., Awang, Z., Jusoff, K., \& Ibrahim, Y. (2017). The influence of green practices by non-green hotels on customer satisfaction and loyalty in hotel and tourism industry. International Journal of Green Economics, 11(1), 1-14.

Zhao, X., Lynch, J.G.J., \& Chen, Q. (2010). Reconsidering Baron and Kenny: Myths and truth about mediation analysis. Journal of Consumer Research, 17, 197-206. 